\title{
Tigecycline pharmacokinetics in critically ill patients on renal replacement therapy: possible warnings and potential perspectives for the research agenda
}

\author{
Salvatore Lucio Cutuli ${ }^{1,2}$, Gennaro De Pascale ${ }^{1,2^{*}} \mathbb{C}$, Lucia Lisi ${ }^{3}$, Simone Carelli ${ }^{1,2}$, Pierluigi Navarra ${ }^{1,3}$ \\ and Massimo Antonelli ${ }^{1,2}$
}

To the editor:

Honore et al. [1] suggested important insights into papers on tigecycline pharmacokinetics/pharmacodynamics in critically ill patients [2,3], which warrant further considerations.

Eleven patients (34.4\%) included in our trial [3] underwent continuous renal replacement therapy with lowadsorptive high-flux membranes (acrylonitrile, AN69), which was set in continuous standard volume venovenous hemodiafiltration (CVVHDF, effluent dose prescribed $35 \mathrm{ml} / \mathrm{kg} / \mathrm{min}$ ) modality and used regional citrate anticoagulation. Although Broeker et al. [2] did not use regional citrate anticoagulation for CVVHDF and such molecule may theoretically interfere with tigecycline plasma protein binding, thus increasing drug-free fraction and extracorporeal removal, the amount of tigecycline clearance was not clinically relevant $(14.8 \%$ or even smaller due to filter performance decrease over time vs

This reply refers to the article available at https://doi.org/10.1186/s13613-02000758-5.

*Correspondence: gennaro.depascalemd@gmail.com

1 Dipartimento di Scienza dell'Emergenza, Anestesiologiche e della

Rianimazione - UOC di Anestesia, Rianimazione, Terapia Intensiva e

Tossicologia Clinica, Fondazione Policlinico Universitario A. Gemelli IRCCS,

00168 Rome, Italy

Full list of author information is available at the end of the article
$13 \%$ of the total elimination via renal excretion [1]) compared to patients with hypoalbuminemia [2]. Such finding is justified by the lipophilic nature of tigecycline (supported by high volume of distribution [2, 3]), which makes the amount of tigecycline removed negligible and disconnected from plasma protein binding and concentration [4].

However, we support the warning launched by Honore et al. [1] about the potential of molecules' removal and consequent need for medication dose adjustments when new membranes are used in daily clinical practice. Furthermore, the greater clearance of antibiotics and small molecules associated with high-volume hemofiltration (effluent dose $70 \mathrm{ml} / \mathrm{kg} / \mathrm{h}$ ), as compared with standard volume hemofiltration reported in the IVOIRE study [5], is a matter of concern. Accordingly, we would suggest to titrate drug prescription during renal replacement therapy to specific membrane characteristics and effluent dose delivered to match patient's need in a timely manner (e.g., acid-base imbalance or fluid overload), especially when hydrophilic medications with low plasma protein binding are prescribed and severe hypoproteinemia occurs [4]. Moreover, we advocate the need for further studies on molecules' removal by renal replacement therapy and other extracorporeal organ supports, to inform clinicians about the impact of new membranes adsorptive properties, at different effluent doses, on drug pharmacokinetics and patients' related outcome. 


\section{Abbreviations}

AN69: Acrylonitrile; CVVHDF: Continuous veno-venous hemodiafiltration.

\section{Acknowledgements}

None.

\section{Authors' contributions}

GDP, MA, LL, and PN conceived the paper, edited the first draft, and reviewed and approved the final draft; SLC edited the first draft, and reviewed and approved the final draft. All authors read and approved the final manuscript.

\section{Funding}

None declared.

\section{Availability of data and materials}

Not applicable.

Ethics approval and consent to participate

Not applicable.

\section{Consent for publication}

Not applicable.

\section{Competing interests}

The authors declare that they have no competing interests.

\section{Author details}

'Dipartimento di Scienza dell'Emergenza, Anestesiologiche e della Rianimazione - UOC di Anestesia, Rianimazione, Terapia Intensiva e Tossicologia Clinica, Fondazione Policlinico Universitario A. Gemelli IRCCS, 00168 Rome, Italy. ${ }^{2}$ Istituto di Anestesia e Rianimazione, Università Cattolica del Sacro Cuore, Rome, Italy. ${ }^{3}$ Institute of Farmacologia, Università Cattolica del Sacro Cuore, L.go F. Vito 1, Rome, Italy.
Received: 19 August 2020 Accepted: 6 October 2020

Published online: 14 October 2020

\section{References}

1. Honore PM, David C, Kugener L, Redant S, Attou R, Gallerani A, De Bels D. No dose adjustment of tigecycline is necessary during continuous renal replacement therapy: we are not sure. Crit Care. 2020;24(59):1-2.

2. Broeker A, Wicha S, Dorn C, Kratzer A, Schleibinger M, Kees F, Heininger A, Kees $\mathrm{M}$, Häberle $\mathrm{H}$. Tigecycline in critically ill patients on continuous renal replacement therapy: a population pharmacokinetic study. Crit Care. 2018;22(1):341

3. De Pascale G, Lisi L, Ciotti GMP, Vallecoccia MS, Cutuli SL, Cascarano L, Gelormini C, Bello G, Montini L, Carelli S, et al. Pharmacokinetics of high-dose tigecycline in critically ill patients with severe infections. Ann Intensive Care. 2020;10(94):1-9.

4. Roberts JA, Lipman J. Pharmacokinetic issues for antibiotics in the critically ill patient. Crit Care Med. 2009;37(3):840-51.

5. Joannes-Boyau O, Honoré PM, Perez P, Bagshaw SM, Grand H, Canivet J-L, Dewitte A, Flamens C, Pujol W, Grandoulier A-S, et al. High-volume versus standard-volume haemofiltration for septic shock patients with acute kidney injury (IVOIRE study): a multicentre randomized controlled trial. Intensive Care Med. 2013;39(9):1535-46.

\section{Publisher's Note}

Springer Nature remains neutral with regard to jurisdictional claims in published maps and institutional affiliations.

\section{Submit your manuscript to a SpringerOpen ${ }^{\odot}$ journal and benefit from:}

- Convenient online submission

- Rigorous peer review

- Open access: articles freely available online

- High visibility within the field

- Retaining the copyright to your article

Submit your next manuscript at $\boldsymbol{\sim}$ springeropen.com 